\title{
FORUM
}

\section{Invasions by Harmonia axyridis (Pallas) (Coleoptera: Coccinellidae) in the Western Hemisphere: Implications for South America}

\author{
Robert L. Koch ${ }^{1}$, Robert C. Venette ${ }^{2}$ and William D. Hutchison ${ }^{1}$ \\ ${ }^{1}$ Dept. Entomology, Univ. Minnesota, 219 Hodson Hall, 1980 Folwell Avenue, St. Paul, Minnesota, 55108, USA \\ ${ }^{2}$ North Central Research Station, USDA Forest Service, 1561 Lindig Avenue, St. Paul, MN 55108, USA
}

Neotropical Entomology 35(4):421-434 (2006)

Invasões de Harmonia axyridis (Pallas) (Coleoptera: Coccinellidae) no Hemisfério Ocidental: Implicacões para a América do Sul

RESUMO - A joaninha, Harmonia axyridis (Pallas), nativa da Ásia, foi recentemente detectada na América do Sul depois de ter invadido a América do Norte e Europa. Essa joaninha é um predador voraz, e portanto, popular e eficaz no controle biológico. Infelizmente, $H$. axyridis também está relacionada a impactos nocivos (ex., como peste residencial e de frutas temperadas e ameaça a organismos não-alvos). Para fazer prever os possíveis impactos de H. axyridis na América do Sul, a história da sua invasão no Hemisfério Ocidental foi revisada e os vários fatores críticos para futuras invasões (isto é, chegada, estabelecimento e disseminação) em novas áreas da América do Sul foram discutidos. A possibilidade de introduções contínuas de H. axyridis na América do Sul parece alta devido a sua popularidade como agente de controle biológico e através de introduções acidentais. Seu estabelecimento também parece possível em extensas regiões da América do Sul. A similaridade climática com a região nativa sugere que o estabelecimento é possível na região sul da América do Sul. Porém, similaridade de hábitat com a região nativa sugere que o estabelecimento seja mais adequado na região norte da América do Sul. Além disso, a disponibilidade da presa não deve ser um fator limitante para o estabelecimento desse predador. Após o estabelecimento, $H$. axyridis pode se disseminar pelo próprio vôo e por meios associados ao homem. Concluindo, a invasão de H. axyridis em novas áreas do continente sul-americano é provável.

PALAVRAS-CHAVE: Controle biológico, espécie invasiva, espécie exótica, similaridade climática, impacto não-alvo

ABSTRACT - The multicolored Asian lady beetle, Harmonia axyridis (Pallas), native to Asia, has recently been detected in South America after successfully invading North America and Europe. This coccinellid is a voracious predator; therefore, it is popular and effective in biological control. Unfortunately, H. axyridis also has associated adverse impacts (i.e., as a household pest, pest of fruit production, and threat to non-target organisms). To predict the potential geographic extent of impacts of $H$. axyridis in South America we review the history of its invasion in the Western Hemisphere and address various factors critical to the future invasion (i.e., arrival, establishment, and spread) of new areas of South America. The likelihood of continued introductions (i.e., arrival) of $H$. axyridis to South America seems high, due to its popularity as a biological control agent and through accidental introductions. Establishment also seems likely in broad regions of South America. Climate matching with the native range suggested that much of southern South America may be suitable for establishment. In contrast, habitat matching with the native range suggested that northern South America may be more suitable. In addition, prey availability should not limit establishment of this predator. Once established, $H$. axyridis seems likely to spread by flight and human-assisted means. Overall, the invasion of $H$. axyridis over broad areas in South America seems likely.

KEY WORDS: Biological control, invasive species, exotic species, climate matching, non-target impact 
The multicolored Asian lady beetle, Harmonia axyridis (Pallas), is a dramatic example of a successful invader. This coccinellid, native to Asia, has become one of the most intensively studied insect predators (Sloggett 2005), with much of this work reviewed by Koch (2003) and Pervez \& Omkar (2006). H. axyridis is a voracious predator of aphids and other soft-bodied insects and has been utilized in numerous biological control programs. This coccinellid is frequently associated with trees in natural and agricultural settings when prey is available (Table 1). In addition, this semi-arboreal predator also occurs in various herbaceous habitats, including agricultural (reviewed by Koch 2003) and natural (Sebolt \& Landis 2004, RLK unpublished data) systems.

Along with beneficial impacts as a biological control agent, $H$. axyridis has shown three general adverse impacts. First, as with many other exotics, $H$. axyridis may threaten native organisms. For example, densities of native predators seem to have decreased as the abundance of $H$. axyridis increased (Colunga-Garcia \& Gage 1998, Brown \& Miller 1998, Michaud 2002b, Alyokhin \& Sewell 2004, Saini 2004), which may be partly due to intraguild predation (e.g., Cottrell \& Yeargan 1998, Michaud 2002b, Cottrell 2004, Yasuda et al. 2004). In addition, H. axyridis may impact populations of the monarch butterfly, Danaus plexippus (Koch et al. 2004c, in press b). Second, H. axyridis can be a pest of fruit production (Koch et al. 2004a), particularly as a contaminant during wine production (Pickering et al. 2004, Galvan et al. 2006). Third, $H$. axyridis can be a nuisance to humans. It can become a household pest when it seeks shelter from winter in homes and other structures (Nalepa et al. $2004,2005)$. Once on or in a home, massive aggregations of $H$. axyridis are a nuisance to homeowners (Nalepa et al. 2004, Huelsman \& Kovach 2004) and can cause allergic reactions in humans (Ray \& Pence 2004). Similarly, $H$. axyridis can form autumn aggregations in bee hives, where it apparently does not harm the bees, but is a nuisance to the bee keepers (Caron 1996).

The geographic range and impacts (both positive and negative) of $H$. axyridis are expanding rapidly. Currently, this coccinellid is widely established in North America [U.S.A and Canada (Koch 2003)], is established and expanding its range in Europe [France (Hodek \& Honik 1996, Lohez 2005), Greece (Katsoyannos et al. 1997), Germany (Bathon 2002, Klausnitzer 2002/3) Belgium (Adriaens et al. 2003), The Netherlands (Cuppen et al. 2004), Switzerland (Klausnitzer 2004), and Britain (Majerus \& Roy 2005)], and is established with a restricted distribution in South America [Brazil (Almeida \& Silva 2002) and Argentina (Saini 2004)]. Can we use what we have learned from the invasion of $H$. axyridis in North America to predict implications for South America? In this paper, we provide a review of the literature on the history of invasions by this coccinellid in the Western Hemisphere. In addition, we make predictions for the spread and impacts of $H$. axyridis in South America, based on evaluation of the suitability of this continent for the primary components of the invasion process (i.e., arrival, establishment and spread) for $H$. axyridis.

\section{Invasion History}

The presumed native distribution of $H$. axyridis extends across southern Siberia from the Altai Mountains to the Pacific Coast, including Korea and Japan, then extends southward to southern China, and includes the Himalayas (Dobzhansky 1933, Chapin 1965, Sasaji 1971, IablokoffKhnzorian 1982, Kuznetsov 1997). Numerous color forms (e.g., the succinea group and various melanic forms) with a genetic basis (mosaic dominance) occur within this range (Komai 1956). In general, the succinea group of $H$. axyridis have an orange-red ground color with or without black spots, whereas numerous melanic forms exist having a black ground color with or without orange-red markings. The relative frequencies of the various forms vary geographically. For instance, the relative frequency of the succinea group increases from west to east across the Asian range (Dobzhansky 1933, Komai 1956). West of Lake Baikal in Russia, the succinea group is rare, but in eastern Siberia it comprises $80 \%$ of the population (Dobzhansky 1933, Komai 1956). Using methods described in Venette and Ragsdale (2004) we determined that the succinea group in Asia is generally associated with biomes characterized by Olson et al. (2001) as boreal forest, temperate broadleaf and mixed forest, temperate coniferous forest, and tropical-subtropical moist broadleaf forest. The melanic group is most commonly associated with boreal forest. In general, melanic color forms of coccinellids may have advantages over their non-melanic counterparts in colder climates. For instance, because the elytra of melanic forms of Adalia bipunctata (L.) have less reflectance than those of non-melanic forms, the melanics are able to attain higher body temperatures relative to ambient temperature than non-melanics when exposed to sunlight. Higher body temperatures during the mating period translate to greater activity, and therefore greater fitness for melanics (Hodek \& Honì k 1996).

Introduction of $H$. axyridis into non-native regions has been extensive. In the following text, we focus primarily on documented intentional releases. However, undocumented commercial releases, unintentional introductions, and unaided dispersal capacity (i.e., flight) have certainly contributed to the extent of its invasion. Records exist of $H$. axyridis being intentionally introduced to North America (Gordon 1985), Europe (Garcia 1986, Ferran et al. 1996, Hodek \& Honì k 1996, Katsoyannos et al. 1997, Trouve et al. 1997, Buzzocchi et al. 2004), Africa (El-Arnaouty et al. 2000, OEPP/EPPO 2002), and South America (Saini 2004). Here, we focus specifically on the invasion history in the Western Hemisphere.

In North America, intentional releases began as early as 1916 in California, with more frequent releases in the U.S.A. and Canada during the 1970's and 1980's (Gordon 1985) into areas with biomes generally classified as temperate broadleaf and mixed forest or temperate coniferous forest (Olson et al. 2001). For example, 87,810 individuals were released from 1978-1981 in Byron, Georgia, U.S.A. (Tedders \& Schaefer 1994) and 37,852 individuals were released from 1981-1982 in three counties of Washington, U.S.A. (LaMana $\&$ Miller 1996). Many of these early releases were targeted 
Table 1. Arboreal hosts (trees and shrubs) and associated preys utilized by H. axyridis.

\begin{tabular}{|c|c|c|}
\hline Host & Reported prey & Reference \\
\hline Abies procera Rehder, noble fir & Cinara sp. (Aphididae) & LaMana \& Miller 1996 \\
\hline Acacia spp., acacia & Psylla uncatoides (Ferris \& Klyver) (Psyllidae) & Leeper \& Beardsley 1974 \\
\hline Acer negundo L., boxelder & Perihpyllus negundinis (Thomas) (Aphididae) & Koch \& Hutchison 2003 \\
\hline Acer saccharum Marsh., sugar maple & $\begin{array}{l}\text { Periphyllus testudinaceae (Fernie), } \\
\text { Drepanaphis idahoensis Smith \& Dilley, } \\
\text { Drepanosiphum platanoides (Schrank) } \\
\text { (Aphididae) }\end{array}$ & LaMana \& Miller 1996 \\
\hline $\begin{array}{l}\text { Betula pendula Roth, European white } \\
\text { birch }\end{array}$ & $\begin{array}{l}\text { Callipterinella calipterus (Hartig), Euceraphis } \\
\text { betulae (Kalterbach) (Aphididae) }\end{array}$ & LaMana \& Miller 1996 \\
\hline $\begin{array}{l}\text { Carya illinoinensis (Wangenh.) K. } \\
\text { Koch, pecan }\end{array}$ & $\begin{array}{l}\text { Monellia caryella (Fitch.), Monelliopsis pecanis } \\
\text { Bissell (Aphididae), Melanocallis caryaefoliae } \\
\text { (Davis) }\end{array}$ & Tedders \& Schaefer 1994 \\
\hline Carya sp. & Monellia caryella (Fitch.) & Saini 2004 \\
\hline $\begin{array}{l}\text { Castanea crenata Sieb. \& Zucc., } \\
\text { chestnut }\end{array}$ & $\begin{array}{l}\text { Diaspidiotus (=Comstockaspis) macroporanus } \\
\text { (Takagi) (Diaspididae) }\end{array}$ & Choi et al. 1995a \\
\hline Citrus spp., citrus & $\begin{array}{l}\text { Diaphorina citri Kuwayama (Psyllidae), } \\
\text { Toxoptera citricida (Kirkaldy) (Aphididae) }\end{array}$ & Michaud 1999, 2002a \\
\hline Fagus sylvatica L., European beech & Phyllaphis fagi (L.) (Aphididae) & LaMana \& Miller 1996 \\
\hline Hibiscus syridis L., hibiscus & Aphis gossypii Glover (Aphididae) & Kindlmann et al. 2000 \\
\hline Juglans regia L., English walnut & $\begin{array}{l}\text { Chromaphis juglandicola (Kaltenbach) } \\
\text { (Aphididae) }\end{array}$ & Li 1992 \\
\hline Lagerstroemia indica $\mathrm{L}$. & $\begin{array}{l}\text { Tinocallis kahawaluokalani (Kirkaldy) } \\
\text { (Aphididae) }\end{array}$ & Almeida \& Silva 2002 \\
\hline Lagerstroemia sp., crape myrtle & $\begin{array}{l}\text { Tinocallis kahawaluokalani (Kirkaldy) } \\
\text { (Aphididae) }\end{array}$ & Chapin \& Brou 1991 \\
\hline Liriodendron tulipifera L., tuliptree & Illinoia liriodendri Monell (Aphididae) & LaMana \& Miller 1996 \\
\hline $\begin{array}{l}\text { Magnolia macrophylla Michaux, } \\
\text { magnolia }\end{array}$ & Not specified & Tedders \& Schaefer 1994 \\
\hline Malus sp., apple & Aphis spiraecola Patch (Aphididae) & Brown \& Miller 1998 \\
\hline Malus sp., dwarf apple & Aphis pomi DeGeer (Aphididae) & Coderre et al. 1995 \\
\hline Malus sp., crab apple & Aphis spiraecola Patch (Aphididae) & Chapin \& Brou 1991 \\
\hline $\begin{array}{l}\text { Pinus densiflora Siebold \& Zucc., } \\
\text { Japanese red pine }\end{array}$ & $\begin{array}{l}\text { Thecodiplosis japonensis Uchida \& Intuye } \\
\text { (Cecidomyiidae), Matsucoccus matsumurae } \\
\text { (Margarodidae) }\end{array}$ & $\begin{array}{l}\text { Miura et al. } 1986 \\
\text { McClure } 1986 b\end{array}$ \\
\hline Pinus massonia Lamb., Chinese red pine & $\begin{array}{l}\text { Matsucoccus matsumurae (Kuwana) } \\
\text { (Margarodidae) }\end{array}$ & Chai 1999 \\
\hline Pinus resinosa Ait., red pine & $\begin{array}{l}\text { Matsucoccus resinosae Bean \& Goodwin } \\
\text { (Margarodidae) }\end{array}$ & McClure 1986a, 1987 \\
\hline Pinus taeda L., loblolly pine & Eulachnus agilis (Kaltenbach) (Aphididae) & Tedders \& Schaefer 1994 \\
\hline $\begin{array}{l}\text { Pinus thunbergiana Franco, Japanese } \\
\text { black pine }\end{array}$ & $\begin{array}{l}\text { Matsucoccus thunbergianae Miller \& Park, } \\
\text { Matsucoccus matsumurae (Margarodidae) }\end{array}$ & $\begin{array}{l}\text { Choi et al. } 1995 \mathrm{~b} \\
\text { McClure } 1986 \mathrm{~b}\end{array}$ \\
\hline Pinus spp. & $\begin{array}{l}\text { Eulachnus agilis (Kaltenbach) (Aphididae), } \\
\text { Cinara atlantica (Wilson), Cinara pinovora } \\
\text { (Wilson) (Aphididae) }\end{array}$ & $\begin{array}{l}\text { Tedders \& Schaefer } 1994 \\
\text { Almeida \& Silva } 2002\end{array}$ \\
\hline
\end{tabular}


Table 1. Continuation

\begin{tabular}{|c|c|c|}
\hline Host & Reported preys & Reference \\
\hline Podocarpus sp. & $\begin{array}{l}\text { Neophyllaphis podocarpi Takahashi } \\
\text { (Aphididae) }\end{array}$ & Tedders \& Schaefer 1994 \\
\hline Prunus persica (L.) Batsch, peach & $\begin{array}{l}\text { Hyalopterus pruni (Geoffroy), Myzus varians } \\
\text { Davidson (Aphididae) }\end{array}$ & Osawa 2000 \\
\hline Prunus sp., plum & Hyalopterus pruni (Geoffrey) (Aphididae) & LaMana \& Miller 1996 \\
\hline Quercus rubra L., northern red oak & Myzocallus occultus Richards (Aphididae) & LaMana \& Miller 1996 \\
\hline Rhamnus sp., buckthorn & Aphis glycines Matsumura (Aphididae) & Hesler et al. 2004 \\
\hline Salix sieboldiana Blume, willow & $\begin{array}{l}\text { Aphis farinosa yanagicola Matsumura, } \\
\text { Tuberolachnus salignus (Gmellin) (Aphididae) }\end{array}$ & Osawa 2000 \\
\hline Salix koriyanagi Kimura, willow & $\begin{array}{l}\text { Chaitophorus horii Takashashi, Tuberolachnus } \\
\text { salignus (Gmelin) (Aphididae) }\end{array}$ & Osawa 2000 \\
\hline Salix sp., willow & Tuberolachnus salignus (Gmelin) (Aphididae) & LaMana \& Miller 1996 \\
\hline $\begin{array}{l}\text { Sambucus sieboldiana Blume, Japanese } \\
\text { elderberry }\end{array}$ & $\begin{array}{l}\text { Aulacorthum magnoliae (Essig \& Kuwana) } \\
\text { (Aphididae) }\end{array}$ & Osawa 2000 \\
\hline Spirea thunbergii Sieb. ex B1. & Aphis spiraecola Patch (Aphididae) & Osawa 2000 \\
\hline Spirea blumei G. Don & Aphis spiraecola Patch (Aphididae) & Osawa 2000 \\
\hline Tilia americana L., American basswood & Eucalypterus tiliae (L.) (Aphididae) & LaMana \& Miller 1996 \\
\hline Tsuga spp., hemlock & Adelges tsugae Annand (Adelgidae) & Wallace \& Hain 2000 \\
\hline Ulmus americana L., American elm & Tinocallis ulmifolii (Monell) (Aphididae) & Hesler 2003 \\
\hline $\begin{array}{l}\text { Zanthoxylum bungeanum Maxim., } \\
\text { Bunge prickly-ash }\end{array}$ & $\begin{array}{l}\text { Phenacoccus azaleae Kuwana } \\
\text { (Pseudococcidae) }\end{array}$ & Xie et al. 2004 \\
\hline
\end{tabular}

at the pecan aphid complex, Melanocallis caryaefoliae (Davis), Monellia caryella (Fitch), and Monelliopsos pecanis Bissel (Tedders \& Schaeffer 1994) and the pear psylla, Cacopsylla pyricola Foerster (LaMana \& Miller 1996). In addition, $H$. axyridis was released for biological control purposes in the Mexican states of Chihuahua (Quiñones et al. 2001), Colima, and Yucatán, (S.H. Tarango Rivero, personal communication). Aside from intentional introductions, it has been argued that accidental sea-port introductions may have played a role in the arrival of this species to North America (Day et al. 1994).

Established populations of $H$. axyridis were first detected in North America in 1988 in southeastern Louisiana, U.S.A. (Chapin \& Brou 1991). The range of $H$. axyridis then expanded rapidly in North America, but spread did not radiate uniformly from the point of first detection (Fig. 1). The beetle population seems to have moved first eastward then to the north. We conjecture that the arrival of $H$. axyridis in Oregon in 1991 resulted from accidental or intentional releases, not from its unaided dispersal from the southeastern U.S.A. For instance, this predator was commercially available as a biological control agent in North America (Heimpel \& Lundgren 2000) and was intentionally redistributed within the continent for biological control purposes, with well documented intentional movement of $H$. axyridis from the southeastern U.S.A. to California and New Mexico, U.S.A in 1992 and 1993 and Texas, U.S.A. in
1994 (Tedders \& Schaefer 1994). It is interesting to note that the extensive spread of $H$. axyridis in North America has occurred despite relatively narrow genetic differentiation of the invading populations (Krafsur et al. 1997).

Currently, $H$. axyridis is nearly ubiquitous in the eastern U.S.A. and southern portions of the eastern Canadian provinces where beetle abundance can be remarkably high (Fig. 1). Likewise, in western North America, this species is distributed along the northern Pacific coast of the U.S.A. and southern coastal area of British Columbia, Canada (Fig. 1). We are currently unaware of $H$. axyridis being present in Montana, (M. Ivie, personal communication), Wyoming (S. Shaw, personal communication), Arizona (D.N. Byrne, personal communication), Hawaii, U.S.A. (F. Howarth \& M.G. Wright, personal communications), or Saskatchewan, Canada (J. Acorn, personal communication). The beetle has been detected in Alberta, Canada but is not known to be established there (J. Acorn, personal communication). In addition, $H$. axyridis is not known to occur in New Mexico, U.S.A, except for a small, irrigated area near the city of Las Cruces (J. Ellington, personal communication). Harmonia axyridis is also present in the following Mexican cities where no intentional releases have been documented: Monticello, Estado de México; Zaragoza, Coahuila; Guadalajara, Jalisco; Cuernavaca, Morelos; and Huejotzingo, Puebla, (S.H. Tarango, personal communication). Densities and impacts of $H$. axyridis in Mexico have yet to be reported. Interestingly, 


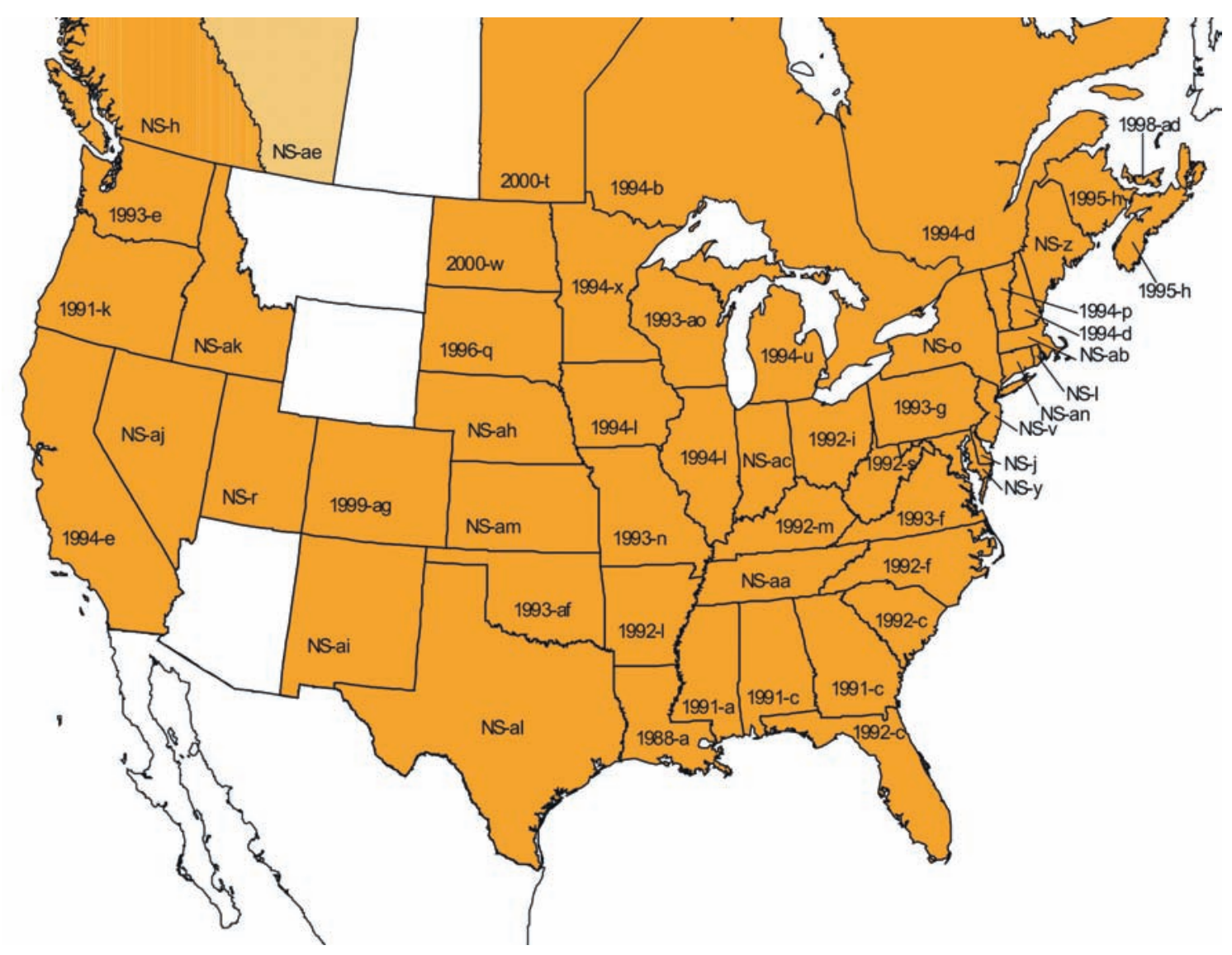

Figure 1. Year of first detection of $H$. axyridis in Canadian provinces and US states. In Alberta, $H$. axyridis has been detected but is not known to be established. (NS-Not specified; a-Chapin \& Brou 1991; b-Ker 1994; c-Tedders \&Schaffer 1994 ; d-Corderre et al. 1995; e-Driestadt et al. 1995; f-Kidd et al. 1995; g-Wheeler 1995; h-Hoebeke \& Wheeler 1996; i-Horn 1996; j-HoughGoldstein et al. 1996; k-LaMana \& Miller 1996; 1-Kafsur et al. 1997; m-Cottrell \& Yeargan 1998; n-Barrett \& Bailey 2000; oRossini et al. 2000; p-Bell 2001; q-Hesler et al. 2001; r-Kalaskar \& Evans 2001; s-McCutcheon \& Scott 2001; t-Wise et al. 2001; u-Ellis et al. 2002; v-Atanassov et al. 2003; w-Fauske et al. 2003; x-Koch \& Hutchison 2003; y-Malinoski 2003; z-Alyokhin \& Sewell 2004; aa-Bost \& Hale 2004; ab-Butin et al. 2004; ac-Rutledge et al. 2004; ad-Majka \& McCorquodale 2006; ae-J. Acorn, personal communication; af-P. Bolin, pers. comm.; ag-W. Cranshaw, pers. comm.; ah- A. Cunninham, pers. comm.; ai-J. Ellington, pers. comm.; aj-J. Knight, pers. comm.; ak-D. Johnson, pers. comm.; al-T.-X. Liu, pers. comm.; am-J.P. Michaud, pers. comm.; an-M.K. Oliver, pers. comm.; and ao-P. Pellitteri, pers. comm.).

the succinea group appears to predominate throughout North America (Chapin \& Brou 1991; Tedders \& Schaefer 1994; Dreistadt et al. 1995; Kidd et al. 1995; LaMana \& Miller 1996; Hesler et al. 2001, 2004; Wise et al. 2001) even though initial colonies of this insect maintained by the United States Department of Agriculture contained the succinea and melanic groups (Krafsur et al. 1997) and both groups were available commercially (e.g., Koch et al. 2004b).

McCorquodale (1998) estimated the rate of $H$. axyridis range expansion in eastern North America (Abitata Springs, LA, U.S.A. to Sydney, NS, Canada) to be $442 \mathrm{~km}$ per year. This rate reflects both the innate dispersal capability and human mediated movement of the insect. However, Hesler et al. (2004) suggest that the rate of range expansion for this semi-arboreal species was considerably lower in South Dakota, U.S.A. perhaps because of the relative paucity of wooded areas in South Dakota and other parts of the central North America compared with eastern North America. Our discussions with other cooperators support the general observation that the westward spread of $H$. axyridis into the Great Plains of the U.S.A. has been slower than the rate of spread along the eastern U.S.A. To determine whether spread might be faster in areas of North America that were more bioclimatically similar to the native Asian range than in areas that were less similar, we first identified the biomes in each state of the U.S.A. or Canadian province and classified each state/province as similar or dissimilar. A state/ province was considered similar when $>50 \%$ of its area was covered with one or more biomes like those found within the native range of $H$. axyridis. We then compared the year of first detection among states/provinces classified as similar with those classified as dissimilar. In general, first detection 
occurred earlier (between 1991 and 1995) in states/provinces with biomes similar to those where $H$. axyridis occurs in Asia than in states/provinces with biomes that are dissimilar (first detected between 1993 and 2000) (Kruskal-Wallis Chisquare $=10.2 ; \mathrm{df}=1 ; \mathrm{P}=0.001)$. However, any estimates of range expansion by $H$. axyridis in North America are likely confounded by the numerous releases of this beetle at multiple locations (McCorquodale 1998) and varying levels of sampling intensity that can affect the date of first detection.

In South America, H. axyridis was intentionally introduced into the state of Mendoza, Argentina in the late 1990's (Saini 2004). Shortly thereafter, the succinea form of the species was recovered in the state of Buenos Aires in northern Argentina where it was associated with Monellia caryella (Fitch) on pecan, Carya illinoinensis (Wangenh.) K. Koch, in 2001 (Saini 2004), and in the city of Curitiba in southern Brazil feeding on Tinocallis kahawaluokalani (Kirkaldy) on crape myrtle, Lagerstroemia indica L., and Cinara atlantica (Wilson) and C. pinivora (Wilson) on pine, Pinus spp., in 2002 (Almeida \& Silva 2002). Curitiba is located in an area of Brazil with a biome classified as tropical and subtropical moist broadleaf forest, which is also found within the native range of $H$. axyridis. In Argentina, both Mendoza and Buenos Aires are predominantly temperate grasslands, savannahs, and shrublands, a biome different from those within the native range of $H$. axyridis, but the same as that of the adventive range in central North America.

\section{Implications for South America}

Questions, developed by the United States National Research Council, specific to various factors affecting each stage of the invasion process (i.e., arrival, establishment, and spread) (Mack et al. 2002) can be used to begin evaluating the likelihood of $H$. axyridis invading South America. In this paper, we provide responses to what we considered the most pertinent questions (Table 2).

Arrival. Since $H$. axyridis has already arrived in South America this stage of the invasion process may seem trivial. However, its importance lies in the potential for additional arrival events by this species in uninvaded areas. The likelihood of continued arrival of $H$. axyridis to South America is high for two reasons. First, continued intentional introduction seem probable, unless regulatory intervention is imposed. This insect has been repeatedly introduced and/ or redistributed intentionally for biological control in North America, Europe, Africa, and South America. Although we are unaware of additional documented releases in the South America, it seems likely, given the popularity of this predator, that more releases for biological control purposes were made or could be made. Second, the likelihood of $H$. axyridis being accidentally introduced into South America also seems high, partly due to the large and expanding overall geographic range of this beetle. With the relatively recent entrance and rapid expansion into the global market by countries like Brazil, $H$. axyridis could accidentally arrive in South America through seaports or other points of entry (e.g., Day et al. 1994). H. axyridis has been detected on cargo crossing the Atlantic (Roy et al. 2005). Therefore, as exports to the South America from countries experiencing large populations of $H$. axyridis continue to increase, the potential for $H$. axyridis accidentally entering South America via cargo shipments will also increase.

Establishment. Outside of its expansive native range, $H$. axyridis has proven capable of establishing populations under a broad range of environmental conditions, particularly in North America. Climate plays an important role in determining the geographic range of ectothermic organisms. Therefore, climate matching between native and potential areas is often used to evaluate the risk of establishment for exotic species (e.g., Baker 2002). Climatic similarities between South America and locations in Asia were measured using climate matching software, CLIMEX (v2, Hearne Scientific, Melbourne), and 0.5 ${ }^{\circ}$-gridded climate data from the Climate Research Unit (Norwich, UK). This software has been used to predict the potential distribution of numerous organisms (e.g., Sutherst et al. 1989, Venette \& Hutchison 1999, Venette \& Ragsdale 2004). Climate data were from 1961-1990. Because the succinea form of $H$. axyridis, predominates in South America (Almeida \& Silva 2002, Saini 2004) and North America (see above), we focused on this form of $H$. axyridis

Table 2. Questions relevant to the invasion of H. axyridis in South America (revised from Mack et al. 2002).

\section{Arrival}

Has the arthropod been recently intercepted in South America?

Does the arthropod have a wide geographic range (proportional to likelihood of transport)?

Does the arthropod, at some times, have high population densities in its native or current range?

\section{Establishment}

Is there a history of establishment in similar habitats elsewhere outside the native range?

Is the climate similar between the current geographic range and potential destinations?

Are potential hosts spatially and temporally available?

\section{Spread}

Does the arthropod have an effective means of dispersal (natural or human-assisted)? 
for our climate-based predictions. Consequently, we restricted comparisons to the eastern extent of the native range of $H$. axyridis, where the succinea form is more abundant. Five locations were identified that spanned the reported latitudinal and longitudinal range of the succinea group of $H$. axyridis in Asia: Chita, Russia; Vladivostok, Russia; Kofu, Japan; Fang'ao, China; and Gongshan, China. Climate matching was performed for the entire year based on average monthly maximum temperature, minimum temperature, total precipitation, and precipitation pattern, all weighted equally. Similarity was expressed as a proportion, with 1.00 reflecting a perfect match between two locations. We also used the biome matching method described in Venette and Ragsdale (2004) to identify which biomes in South America might provide suitable habitat based on the distribution of the succinea group in Asia.

South America is climatically diverse, and the degree of similarity to the native range of $H$. axyridis varies considerably depending on where comparisons are made. The climate in Asia associated with the northern, native range of the beetle was most similar to the higher elevations in the mountainous terrain of Chile, Bolivia and Peru (Fig. $2 \mathrm{~A}, \mathrm{~B})$. The southerly range of the beetle is most similar to southern Brazil and northern Argentina (Fig. 2C, D, E). None of the locations in Asia closely matched the climate of northern Brazil (Fig. 2). In general, the southern half of South America appears to have a high degree of climatic similarity and might be assumed to be suitable for establishment for $H$. axyridis. Likewise, the comparison of biomes suggests that large areas of South America should provide suitable habitat (Fig. 3), but the most suitable areas are different from those areas highlighted by the climate analysis. In fact, the biome analysis suggests northern Brazil with tropical and subtropical moist broadleaf forests should provide a suitable habitat. How do we reconcile these conflicting predictions?

A poor climatic match does not necessarily mean an area is not suitable for establishment. For example, average high temperatures near Gongshan, China vary between $13-23^{\circ} \mathrm{C}$ during a year, and average low temperatures vary between $0-15^{\circ} \mathrm{C}$. In contrast, average high temperatures near Manaus, in northern Brazil only fluctuate between $30-33^{\circ} \mathrm{C}$ during a year, and low temperatures vary between $23-24^{\circ} \mathrm{C}$. Based on maximum temperature and minimum temperature, similarity indices between the two locations were only 0.16 and 0.11 , respectively, out of 1.00 . When precipitation is factored, the composite match index climbs to 0.32 out of 1.00. On all measures, the climates of the two locations seem dissimilar. However, $H$. axyridis begins to develop between $\sim 8^{\circ} \mathrm{C}$ (Soares et al. 2003) and $\sim 11^{\circ} \mathrm{C}$ (LaMana \& Miller 1998). Development is most rapid at $\sim 30^{\circ} \mathrm{C}$ (Schanderl et al. 1985). Likewise, females are mated more quickly at $30^{\circ} \mathrm{C}$ than at cooler temperatures (Stathas et al. 2001). Metabolic patterns indicate that temperatures of $35^{\circ} \mathrm{C}$ begin to stress second instars and adults (Acar et al. 2004). Mortality of these stages is high at $40^{\circ} \mathrm{C}$, but all other stages survive (Acar et al. 2004). Thus, although temperatures in equatorial Brazil are considerably warmer than in Gongshan, China, these temperatures do not seem sufficiently extreme to preclude establishment. In addition, no evidence suggests $H$. axyridis has obligatory diapause or requires cold exposure to mature reproductively.

Eco-climatic predictions of a species potential distribution can be based on a solid understanding of the known distribution of the species or biological parameters specific to that species (Baker 2002). However, for $H$. axyridis, only coarse descriptions of the native distribution have been provided. Further work is needed to provide a more detailed understanding of this species' native range. In addition, more work is needed to develop parameters describing this species' response to various environmental conditions to allow for more detailed modeling of its population dynamics and potential distribution in South America.

The likelihood of establishment also depends on the availability of prey. Native aphid species are relatively sparse in South America (Dixon 1985; Blackman \& Eastop 1994, 2000). However, this fact will likely have little impact on the probability of $H$. axyridis establishment for two reasons. First, exotic aphid species have colonized plants and become pests in South America (Blackman \& Eastop 2000). Second, although $H$. axyridis is primarily aphidophagous, it will feed on numerous other insect prey (e.g., Tetranichidae, Psyllidae, Coccoidea, Chrysomelidae, Curculionidae, and Lepidoptera) and plant material (e.g., damaged fruit, pollen, and nectar) (Koch 2003). Therefore, the potential lack of aphid prey in South America may be compensated for by the increased relative numbers of other prey, such as Psyllidae (Blackman \& Eastop 1994), Aleyrodidae, and Coccoidea (Dixon 1985).

Spread. H. axyridis possesses exceptional means of dispersal. As reviewed above, because of its value for biological control, this predator will often be collected and redistributed or mass-reared and released into locations it has not yet invaded. In addition, its tendency to aggregate in concealed locations on prominent objects prior to overwintering may increase the likelihood of $H$. axyridis going undetected and being unintentionally transported via plane, train, truck, or ship to new locations. Furthermore, coccinellids have potential to fly great distances (Hodek \& Honì $\mathrm{k}$ 1996). Based on the relatively slow spread of $H$. axyridis through the temperate grasslands, savannahs, and shrublands of the central U.S.A. (see above), it seems likely that its spread in Argentina and other areas similar to the central U.S.A. may experience slightly slower rates of range expansion than areas with biomes like those found in the Asian native range and eastern and western North America.

\section{Conclusions}

Overall, the invasion of $H$. axyridis over broad areas in South America seems likely. Once established, eradication of exotic, invasive species is difficult to impossible. Because of this, efforts should be focused not on elimination of widespread established populations of $H$. axyridis, but on learning how to slow the spread and cope with the presence of this exotic organism. To slow the spread of $H$. axyridis, 

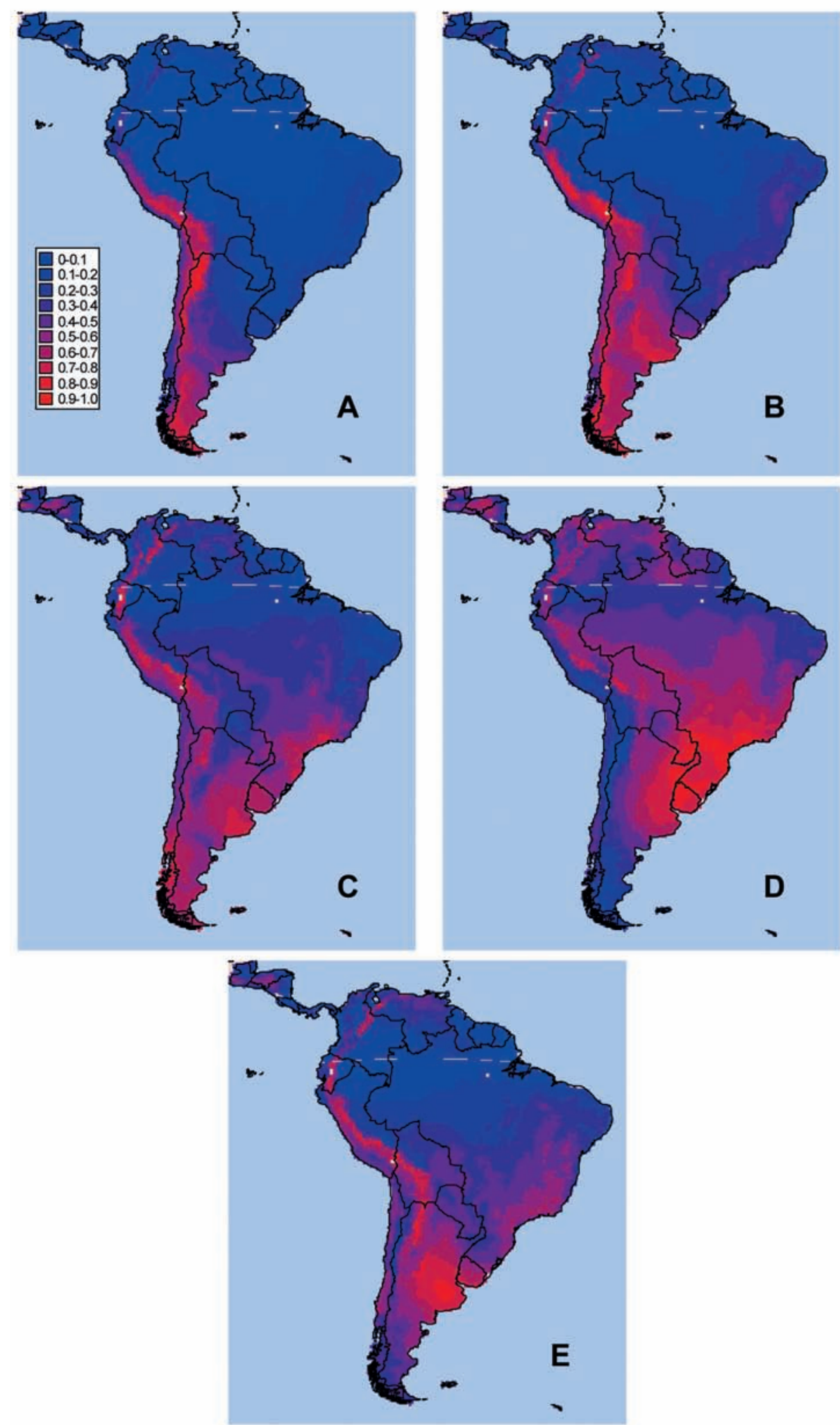

Figure 2. Climatic similarity of South America and southern Central America to Asian cities with succinea forms of $H$. axyridis: A) Chita, Russia [52.0 $\left.{ }^{\circ} \mathrm{N}, 113.6^{\circ} \mathrm{E}\right]$; B) Vladivostok, Russia [43. $\left.1^{\circ} \mathrm{N}, 131.9^{\circ} \mathrm{E}\right]$; C) Kofu, Japan [35. $\left.7^{\circ} \mathrm{N}, 138.6^{\circ} \mathrm{E}\right]$; $\mathrm{D}$ ) Fang'ao, China $\left[27.9^{\circ} \mathrm{N}, 120.6^{\circ} \mathrm{E}\right]$; and E) Gongshan, China $\left[25.8^{\circ} \mathrm{N}, 103.2^{\circ} \mathrm{E}\right]$. 


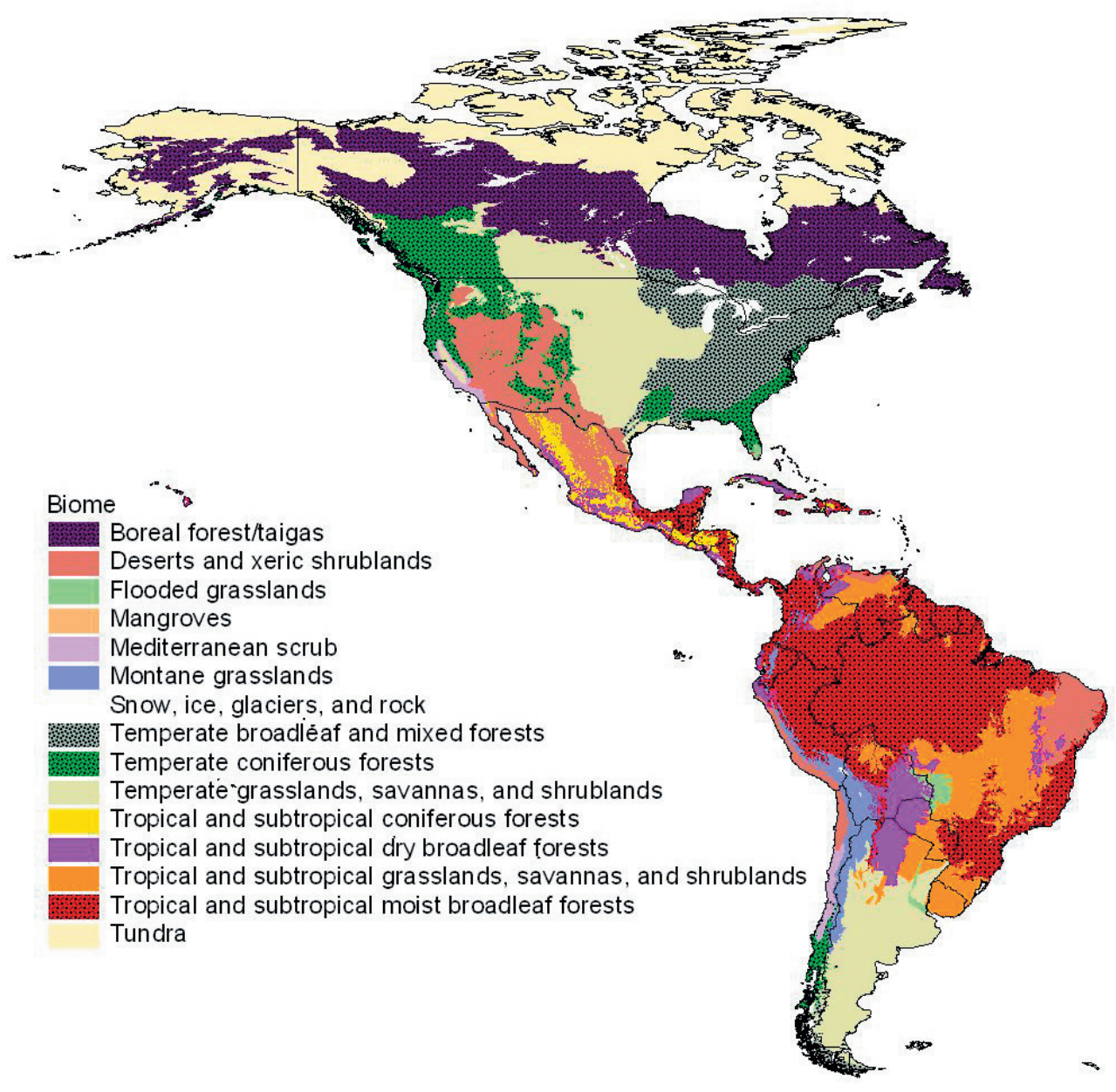

Figure 3. Biomes of the Western Hemisphere as defined by Olson et al. (2001). Dots indicate biomes occupied by H. axyridis in Asia.

we must explore techniques to minimize the likelihood of further human aided dispersal of $H$. axyridis. This could include increased sampling efforts at points of entry into areas where $H$. axyridis is not yet established. Furthermore, we should consider putting an end to the mass rearing and release of this natural enemy for biological control purposes into areas where it has not yet established. However, because $H$. axyridis will likely become permanently established in many of the areas it has invaded, we must continue to advance our knowledge on how to reap benefits in situations where $H$. axyridis is a potential biological control agent and mitigate its effects in situations where it is a potential pest (e.g., as a household pest, pest of fruit production and threat to non-target organisms). For instance, further work is needed to promote the potential biological control offered by this predator and to begin incorporating it into existing integrated pest management programs (e.g., Musser \& Shelton 2003; Musser et al. 2004; Galvan et al. 2005a, $2005 \mathrm{~b}$, in press; Koch et al. in press a). In contrast, continued work is needed to aid in management of this pest in household (e.g., Nalepa et al. 2004, 2005) and fruit production (e.g., Koch et al. 2004a, Pickering et al. 2004, Galvan et al. 2006) situations. In addition, caution should be taken if trying to promote populations of this predator for biological control, so that impacts on non-target organisms can be minimized. Furthermore, if action is taken to suppress populations of $H$. axyridis, what non-target impacts could result from such intervention?

The multiple invasions of $H$. axyridis across the globe provide us with a unique opportunity to examine invasion biology. Essentially, we have two replications of the invasion process on continental scales in North America and Europe, and a third replication of this invasion process beginning in South America. As a scientific community we could benefit greatly from more coordinated research efforts among countries within continents and among continents.

\section{Acknowledgements}

We thank the editorial board of Neotropical Entomology for inviting us to contribute this paper. In addition, we thank K. Wyckhuys, T. Galvan, M. Carrillo and Y. Hu (University 
of Minnesota) for translating literature, G. Heimpel, K. Wyckhuys and T. Galvan (University of Minnesota) for reviewing an early version of this paper, and S. Nogueira Koch and T. Galvan (University of Minnesota) for assistance translating the abstract from English to Portuguese. Furthermore, we thank to the following people for providing information on the current distribution of $H$. axyridis: J. Acorn (University of Alberta); R.T. Bell (University of Vermont); P. Bolin (Oklahoma State University); D.N. Byrne (University of Arizona); N. Carter (Ontario Ministry of Agriculture and Food); W. Cranshaw (Colorado State University); A. Cunningham (University of Nebraska); J. Ellington (New Mexico State University); G. Fauske (North Dakota State University); L. Hesler (United States Department of Agriculture, South Dakota); F. Howarth (Bishop Museum, Hawaii); M. Ivie (Montana State University); D. Johnson (University of Idaho); J. Knight (Nevada Division of Agriculture); T.-X. Liu (Texas A\&M University); J.P. Michaud (Kansas State University); M.K. Oliver; P. Pellitteri (University of Wisconsin); S. Shaw (University of Wyoming); S.H. Tarango Rivero (CEDELINIFAP, Mexico); and M.G. Wright (University of Hawaii). This research was funded by the University of Minnesota Experiment Station and the University of Minnesota Doctoral Dissertation Fellowship awarded to R.L.K.

\section{References}

Acar, E.B., D.D. Mill, B.N. Smith, L.D. Hansen \& G.M. Booth. 2004. Calorespirometric determination of the effects of temperature on metabolism of Harmonia axyridis (Col: Coccinellidae) from second instars to adults. Environ. Entomol. 33: 832-838.

Adriaens, T., E. Branquart \& D. Maes. 2003. The multicoloured Asian ladybird Harmonia axyridis Pallas (Coleoptera: Coccinellidae), a threat for native aphid predators in Belgium? Belg. J. Zool. 133: 195-196.

Almeida, L.M. de \& V.B. da Silva. 2002. First record of Harmonia axyridis (Pallas) (Coleoptera, Coccinellidae): a lady beetle native to the Palaearctic region. Rev. Bras. Zool. 19: 941944.

Alyokhin, A. \& G. Sewell. 2004. Changes in a lady beetle community following the establishment of three alien species. Biol. Invasions 6: 463-471.

Atanassov A., P.W. Shearer \& G.C. Hamilton. 2003. Peach pest management programs impact beneficial fauna abundance and Grapholita molesta (Lepidoptera: Tortricidae) egg parasitism and predation. Environ. Entomol. 32: 780-788.

Baker, R.H.A. 2002. Predicting the limits to potential distribution of alien crop pests, p. 207-241. In G.J. Hallman \& C.P. Schwalbe (eds.), Invasive arthropods in agriculture. Science Publishers, Enfield, NH (U.S.A.), 447p.

Bathon, H. 2002. Harmonia axyridis, eine invasive Marienkaferart in Mitteleuropa. DGaaE Nachrichten 16: 109-110.

Barrett, B. \& W. Bailey. 2000. Multicolored Asian lady beetle. University of Missouri, Extension Publication G7369, 2p.
Bell, R.T. 2001. Introducing a new ladybird beetle to Vermont called Harmonia axyridis (Family:Coccinellidae). Vermont Entomological Society \& University of Vermont. http:// www.uvm.edu/ rtbell/Ladybug.html

Blackman, R.L. \& V.F. Eastop. 1994. Aphids on the world's trees: An identification and information guide. Wallingford, CAB International, $987 \mathrm{p}$.

Blackman, R.L. \& V.F. Eastop. 2000. Aphids on the world's crops: An identification and information guide. Chichester, John Wiley \& Sons, Ltd., 466p.

Bost, S. \& F. Hale. 2004. Multicolored Asian lady beetles and wine grapes. Fruit Pest News v. 5. University of Tennessee Extension Service. http:/web.utk.edu/ extepp/fpn/ fpn081004.htm

Butin, E.E., N.P. Havill, J.S. Elkinton \& M.E. Montgomery. 2004. Feeding preference of three lady beetle predators of the hemlock woolly adelgid (Homoptera: Adelgidae). J. Econ. Entomol. 97: 1635-1641.

Buzzocchi, G.G., A. Lanzoni, G. Accinelli \& G. Burgio. 2004. Overwintering, phenology and fecundity of Harmonia axyridis in comparison with native coccinellid species in Italy. BioControl 49: 245-260.

Brown, M.W. \& S.S. Miller. 1998. Coccinellidae (Coleoptera) in apple orchards of eastern West Virginia and the impact of invasion by Harmonia axyridis. Entomol. News 109: 136142.

Caron, D.M. 1996. Multicolored Asian lady beetles: A "new" honey bee pest. Am. Bee J. 136: 728-729.

Chai, X. 1999. Predatory enemies of Matsucoccus matsumurae and their population dynamics. J. Zhejiang Forestry Col. 16: 336-340.

Chapin, E.A. 1965. Coccinellidae, Coleoptera. Insects of Micronesia. 16: 189-254.

Chapin, J.B. \& V.A. Brou. 1991. Harmonia axyridis (Pallas), the third species of the genus to be found in the United States (Coleoptera: Coccinellidae). Proc. Entomol. Soc. Wash. 93: 630-635.

Choi, K., J. Kim \& S. Lee. 1995a. Host plants of Comstockaspis macroporanus and its predators. J. Forest Sci. (Seoul) 51: 143-146.

Choi, K., S. Lee, J. Kim \& J. Park. 1995b. Role of the coccinellid beetle, Harmonia axyridis, in the biological control of the black pine blast scale insect, Matsucoccus thunbergianae. J. Forest Sci. (Seoul) 51: 115-118.

Coderre, D., É. Lucas \& I. Gagné. 1995. The occurrence of Harmonia axyridis (Pallas) (Coleoptera: Coccinellidae) in Canada. Can. Entomol. 127: 609-611.

Colunga-Garcia, M. \& S.H. Gage. 1998. Arrival, establishment, and habitat use of the multicolored Asian lady beetle (Coleoptera: Coccinellidae) in a Michigan landscape. Environ. Entomol. 27: 1574-1580.

Cottrell, T.E. 2004. Suitability of exotic and native ladybeetle eggs (Coleoptera: Coccinellidae) for development of lady beetle 
larvae. Biol. Control 31: 362-371.

Cottrell, T.E. \& K.V. Yeargan. 1998. Intraguild predation between an introduced lady beetle, Harmonia axyridis (Coleoptera: Coccinellidae), and a native lady beetle, Coleomegilla maculata (Coleoptera: Coccinellidae). J. Kans. Entomol. Soc. 71: 159-163.

Cuppen, J., T. Heijerman, P. van Wielink \& A. Loomans. 2004. Het lieveheersbeestje Harmonia axyridis in Nederland: een aanwinst voor onze fauna of een ongewenste indringer (Coleoptera: Coccinellidae)? Nederlandse Faunistische Mededelingen 20: 1-12.

Day, W.H., D.R. Prokrym, D.R. Ellis \& R.J. Chianese. 1994. The known distribution of the predator Propylea quatuordecimpunctata (Coleoptera: Coccinellidae) in the United States, and thoughts on the origin of this species and five other exotic lady beetles in eastern North America. Entomol. News 105: 224-256.

Dixon, A.F.G. 1985. Aphid ecology. London, Chapman and Hall, 300 p.

Dobzhansky, T. 1933. Geographical variation in ladybeetles. Am. Nat. 67: 97-126.

Dreistadt, S.H., K.S. Hagen \& L.G. Bezark. 1995. Harmonia axyridis (Pallas) (Coleoptera: Coccinellidae), first western United States record for this Asiatic lady beetle. Pan-Pac. Entomol. 71: 135-136.

El-Arnaouty, S.A., V. Beyssat-Arnaouty, A. Ferran \& H. Galal. 2000. Introduction and release of the coccinellid Harmonia axyridis Pallas for controlling Aphis craccivora Koch on faba beans in Egypt. Egypt. J. Biol. Pest Control 10: 129-136.

Ellis, T., R. Isaacs, D. Landis \& J. Landis. 2002. FAQ Frequently asked questions: The multicolored Asian lady beetle. Michigan State University Integrated Pest Management Resources, Michigan State University Extension (http:// www.ipm.msu.edu/beetleFAQ.htm).

Fauske, G.M., P.P. Tinerella \& D.A. Rider. 2003. A list of the lady beetles (Coleoptera: Coccinellidae) of North Dakota with new records from North Dakota and Minnesota. J. Kans. Entomol. Soc. 76: 38-46.

Ferran, A., H. Niknam, F. Kabiri, J.L. Picart, C. de Herce, J. Brun, G. Iperti \& L. Lapchin. 1996. The use of Harmonia axyridis larvae (Coleoptera: Coccinellidae) against Macrosiphum rosae (Hemiptera: Sternorrhyncha: Aphididae) on rose bushes. Eur. J. Entomol. 93: 59-67.

Galvan, T.L., R.L. Koch \& W.D. Hutchison. 2005a. Effects of spinosad and indoxacarb on survival, development and reproduction of the multicolored Asian lady beetle (Coleoptera: Coccinellidae). Biol. Control 34: 108-114.

Galvan, T.L., R.L. Koch \& W.D. Hutchison. 2005b. Toxicity of commonly used insecticides in sweet corn and soybean to the multicolored Asian lady beetle (Coleoptera: Coccinellidae). J. Econ. Entomol. 98: 780-789.

Galvan, T.L., E.C. Burkness \& W.D. Hutchison. 2006. Wine grapes in the Midwest: Reducing the risk of the multicolored Asian lady beetle. Publication 08232. University of Minnesota Extension Service, St. Paul, MN, 2p.

Galvan, T.L., R.L. Koch \& W.D. Hutchison. (in press). Toxicity of spinosad and indoxacarb to the multicolored Asian lady beetle (Coleoptera: Coccinellidae) via three routes of exposure. Pest Manag. Sci.

Garcia, V. 1986. Approaches to integrated control of some citrus pests in the Azores and Algarve (Portugal) p. 557-559. In R. Cavalloro \& E.D. Martino (eds.), Integrated pest control in citrus groves. Commission of the European Communities Proceedings of the Experts' Meeting, Acireale, Italy, 26-29 March 1985. Rotterdam, A.A. Balkema, 600p.

Gordon, R.D. 1985. The Coccinellidae (Coleoptera) of America north of Mexico. J. New York Entomol. Soc. 93: 1-912.

Heimpel, G.E. \& J.G. Lundgren. 2000. Sex ratios of commerciallyreared biological control agents. Biol. Control 19: 77-93.

Hesler, L.S. 2003. Large summer population of multicolored Asian lady beetle in North Dakota. Prairie Nat. 35: 287-289.

Hesler, L.S., R.W. Kieckhefer \& D.A. Beck. 2001. First record of Harmonia axyridis (Coleoptera: Coccinellidae) in South Dakota and notes on its activity there and in Minnesota. Entomol. News 112: 264-270.

Hesler, L.S., R.W. Kieckhefer \& M.A. Catangui. 2004. Surveys and field observations of Harmonia axyridis and other Coccinellidae (Coleoptera) in eastern and central South Dakota. Trans. Am. Entomol. Soc. 130: 113-133.

Hoebeke, E.R. \& A.G. Wheeler. 1996. Adventive lady beetles (Coleoptera: Coccinellidae) in the Canadian maritime provinces, with new eastern U.S. records of Harmonia quadripunctata. Entomol. News 107: 281-290.

Hodek, I. \& A. Honì k. 1996. Ecology of Coccinellidae. Dordrecht, Kluwer Academic Press, 464 p.

Horn, D.J. 1996. Impacts of non-indigenous arthropods in biological control. Midwest Biol. Control News: Online, vol. 3 (http:// www.entomology.wisc.edu/mbcn/fea312.html).

Hough-Goldstein, J., J. Cox \& A. Armstrong. 1996. Podisus maculiventris (Hemiptera: Pentatomidae) predation on ladybird beetles (Coleoptera: Coccinellidae). Florida Entomol. 79: 64-68.

Huelsman, M.F. \& J. Kovach. 2004. Behavior and treatment of the multicolored Asian lady beetle (Harmonia axyridis) in urban environments. Am. Entomol. 50: 163-164

Iablokoff-Khnzorian, S.M. 1982. Les coccinelles ColéoptèresCoccinellidae: Tribu Coccinellini des régions Paléarctique et Orientale. Paris, Société Nouvelle des Éditions Boubée, 568p.

Kalaskar, A. \& E.W. Evans. 2001. Larval responses of aphidophagous lady beetles (Coleoptera: Coccinellidae) to weevil larvae versus aphids as prey. Ann. Entomol. Soc. Am. 94: 76-81.

Katsoyannos, P., D.C. Kontodimas, G.J. Stathas \& C.T. Tsartalis. 1997. Establishment of Harmonia axyridis on citrus and some data on its phenology in Greece. Phytoparasitica 25: 183-191. 
Ker, K.W. 2002. Questions and answers about Harmonia axyridis (Pallas) the multicolored Asian lady beetle. Agnet (http:// archives.foodsafetynetwork.ca/agnet/2002/6-2002/ agnet_june_12-3.htm).

Kidd, K.A., C.A. Nalepa, E.R. Day \& M.G. Waldvogel. 1995. Distribution of Harmonia axyridis (Pallas) (Coleoptera: Coccinellidae) in North Carolina and Virginia. Proc. Entomol. Soc. Wash. 97: 729-731.

Kindlmann, P., H. Yasuda, S. Sato \& K Shinya. 2000. Key life stages of two predatory ladybird species (Coleoptera: Coccinellidae). Eur. J. Entomol. 97: 495-499.

Klausnitzer, B. 2002/3. Harmonia axyridis (Pallas, 1773) in Deutschland (Col., Coccinellidae). Entomol. Nachrichten Berichte 46: 177-183.

Klausnitzer, B. 2004. Harmonia axyridis (Pallas, 1773) in BaselStadt (Coleoptera, Coccinellidae). Mitteilungen Entomol. Gesellschaft Basel 54: 115-122.

Koch, R.L. 2003. The multicolored Asian lady beetle, Harmonia axyridis: A review of its biology, uses in biological control and non-target impacts. J. Insect Sci. 3: 1-16 (http:// www.insectscience.org/3.32).

Koch, R.L., E.C. Burkness, S.J. Wold Burkness \& W.D. Hutchison. 2004a. Phytophagous preferences of the multicolored Asian lady beetle (Coleoptera: Coccinellidae) to autumn ripening fruit. J. Econ. Entomol. 97: 539-544.

Koch, R.L., E.C. Burkness \& W.D. Hutchison. (in press)a. Spatial distribution and fixed-precision sampling plans for the ladybird Harmonia axyridis in sweet corn. BioControl.

Koch, R.L., M.A. Carrillo, R.C. Venette, C.A. Cannon \& W.D. Hutchison. 2004b. Cold hardiness of the multicolored Asian lady beetle (Coleoptera: Coccinellidae). Environ. Entomol. 33: $815-822$.

Koch, R.L., R.C. Venette \& W.D. Hutchison. 2004c. Nontarget effects of the multicolored Asian lady beetle (Coleoptera: Coccinellidae): Case study with the monarch butterfly (Lepidoptera: Nymphalidae). Am. Entomol. 50: 155-156.

Koch, R.L., R.C. Venette \& W.D. Hutchison. (in press)b. Predicted impact of an exotic generalist predator on monarch butterfly (Lepidoptera: Nymphalidae) populations: A quantitative risk assessment. Biol. Invasions.

Koch, R.L. \& W.D. Hutchison. 2003. Phenology and blacklight trapping of the multicolored Asian lady beetle (Coleoptera: Coccinellidae) in a Minnesota agricultural landscape. J. Entomol. Sci. 38: 477-480.

Komai, T. 1956. Genetics of ladybeetles. Adv. Genet. 8: 155-188.

Krafsur, E.S., T.J. Kring, J.C. Miller, P. Nariboli, J.J. Obrycki, J.R. Ruberson \& P.W. Schaefer. 1997. Gene flow in the exotic colonizing ladybeetle Harmonia axyridis in North America. Biol. Control 8: 207-214.

Kuznetsov, V.N. 1997. Lady Beetles of the Russian Far East. Memoir No. 1. Center for Systematic Entomology. Gainsville, Sandhill Crane Press, Inc., 248p.
LaMana, M.L. \& J.C. Miller. 1996. Field observations on Harmonia axyridis Pallas (Coleoptera: Coccinellidae) in Oregon. Biol. Control 6: 232-237.

LaMana, M.L. \& J.C. Miller. 1998. Temperature-dependent development in an Oregon population of Harmonia axyridis (Coleoptera: Coccinellidae). Environ. Entomol. 27: 10011005.

Leeper, J.R. \& J.W. Beardsley Jr. 1974. The biological control of Psylla uncatoides (Ferris \& Klyver) (Homoptera: Psyllidae) on Hawaii. Proc. Hawaii. Entomol. Soc. 22: 307-321.

Li, J.P. 1992. Morphology and bionomics of Chromaphis juglandicola Kaltenback and its control. Entomol. Knowl. 29: 345-347.

Lohez, D. 2005. Harmonia axyridis Pallas (Coleoptera Coccinellidae) une coccinelle venue d'ailleurs Bull. Soc. Entomol Nord France 315: 8-9.

Mack, R.N., S.C.H. Barrett, P.L. deFur, W.L. MacDonald, L.V. Madden, D.S. Marshall, D.G. McCullough, P.B. McEvoy, J.P. Nyrop, S.E.H. Reichard, K.J. Rice \& S.A. Tolin. 2002. Predicting invasions of nonindigenous plants and plant pests. Washington, National Academy of Sciences, 194p.

Majerus, M.E.N. \& H.E. Roy. 2005. Scientific opportunities presented by the arrival of the harlequin ladybird, Harmonia axyridis, in Britain. Bull. Royal Entomol. Soc. (Antenna) 29: 196-208.

Majka, C.G. \& D.B. McCorquodale. 2006. The Coccinellidae (Coleoptera) of the Maritime Provinces of Canada: New records, biogeographic notes, and conservation concerns. Zootaxa 1154: 49-68.

Malinoski, M.K. 2003. The multicolored Asian lady beetle: mixed blessing. Invasive species of concern in Maryland. University of Maryland, Home and Garden Information Center. http:// ww w. mdinvasivesp.org/archived_invaders/ archived_invaders_2003_10.html

McClure, M.S. 1986a. Importing ladybird beetles to control red pine scale. Front. Plant Sci. 39: 5-7.

McClure, M.S. 1986b. Role of predators in regulation of endemic populations of Matsucoccus matsumurae (Homoptera: Margarodidae) in Japan. Environ. Entomol. 15: 976-983.

McClure, M.S. 1987. Potential of the Asian predator, Harmonia axyridis Pallas (Coleoptera: Coccinellidae), to control Matsucoccus resinosae Bean and Godwin (Homoptera: Margarodidae) in the United States. Environ. Entomol. 16: 224-230.

McCorquodale, D.B. 1998. Adventive lady beetles (Coleoptera: Coccinellidae) in eastern Nova Scotia, Canada. Entomol. News 109: 15-20.

McCutcheon, T.W. \& H.R. Scott. 2001. Observations of cosmetic damage on a house caused by the multicolored Asian lady beetle, Harmonia axyridis (Coleoptera: Coccinellidae). West Virginia University Extension Service (http://www.wvu.edu/ $\sim$ agexten/ipm/insects/beetle.pdf) 
Michaud, J.P. 1999. Sources of mortality in colonies of brown citrus aphid, Toxoptera citricida. BioControl 44: 347-367.

Michaud, J.P. 2002a. Biological control of Asian citrus psyllid, Diaphorina citri (Hemiptera: Psyllidae) in Florida: A preliminary report. Entomol. News 113: 216-222.

Michaud, J.P. 2002b. Invasion of the Florida Citrus ecosystem by Harmonia axyridis (Coleoptera: Coccinellidae) and asymmetric competition with a native species, Cycloneda sanguinea. Environ. Entomol. 31: 827-835.

Miura, T., K. Yano, Y. Maeta \& B.Y. Lee. 1986. Selected insects in pine forests infected by the pine gall midge in Korea. Bull. Fac. Agric. Shimane Univ. 20: 176-190

Mondor, E.B. \& J.L. Warren. 2000. Unconditioned and conditioned responses to colour in the predatory coccinellid, Harmonia axyridis (Coleoptera: Coccinellidae). Eur. J. Entomol. 97: 463467.

Musser, F.R. \& A.M. Shelton. 2003. Bt sweet corn and selective insecticides: impacts on pests and predators. J. Econ. Entomol. 96: 71-80.

Musser, F.R., J.P. Nyrop \& A.M. Shelton. 2004. Survey of predators and sampling method comparison in sweet corn. J. Econ. Entomol. 97: 136-144.

Nalepa, C.A., G.C. Kennedy \& C. Brownie. 2004. Orientation of multicolored Asian lady beetles to buildings. Am. Entomol. 50: 165-166.

Nalepa, C.A., G.C. Kennedy \& C. Brownie. 2005. Role of visual contrast in the alighting behavior of Harmonia axyridis (Coleoptera: Coccinellidae) at overwintering sites. Environ. Entomol. 34: 425-431.

OEPP/EPPO. 2002. List of biological control agents widely used in the EPPO region. EPPO Bull. 32: 447-461.

Olson, D.M., E. Dinerstein, E.D. Wikramanayakw, N.D. Burgess, G.V.N. Powell, E.C. Underwood, J.A. D’Amico, I. Itoua, H.E. Strand, J.C. Morrison, C.J. Loucks, T.F. Allnutt, T.H. Ricketts, Y. Kura, J.F. Lamoreux, W.W. Wettengel, P. Hedao \& K.R. Kassem. 2001. Terrestrial ecoregions of the world: A new map of life on Earth. BioSci. 51: 933-938.

Osawa, N. 2000. Population field studies on the aphidophagous ladybird beetle Harmonia axyridis (Coleoptera: Coccinellidae): Resource tracking and population characteristics. Popul. Ecol. 42: 115-127.

Pervez, A. \& Omkar. 2006. Ecology and biological control application of multicoloured Asian ladybird, Harmonia axyridis: A review. Biocontrol Sci. Tech. 16: 111-128.

Pickering, G., J. Lin, R. Riesen, A. Reynolds, I. Brindel \& G. Soleas. 2004. Influence of Harmonia axyridis on the sensory properties of white and red wine. Am. J. Enol. Vitic. 55: 153159.

Quiñones Pando, FJ. N. Chávez Sánchez. \& S.H. Tarango Rivero. 2001. Efecto del tiempo de disponibilidad del macho en la fecundidad de Harmonia axyridis Pallas (Coleoptera: Coccinellidae). Folia Entomol. Mex. 40: 47-52.
Ray, J.N. \& H.L. Pence. 2004. Ladybug hypersensitivity: Report of a case and review of literature. Allergy Asthma Proc. 25: 133-136.

Rossini, C., A. Gonzalez, J. Farmer, J. Meinwald \& T. Eisner. 2000. Antiinsectan activity of epilachnene, a defensive alkaloid from pupae of Mexican bean beetles (Epilachna varivestis). J. Chem. Ecol. 26: 391-397.

Roy, H., F. Rowland, P. Brown, R. Ware \& M. Majerus. 2005. Ecology of the harlequin ladybird - a new invasive species. British Wildlife 16: 403-407.

Rutledge, C.E., R.J. O’Neil, T.B. Fox \& D.A. Landis. 2004. Soybean aphid predators and their use in integrated pest management. Ann. Entomol. Soc. Am. 97: 240-248.

Saini, E.D. 2004. Presencia de Harmonia axyridis (Pallas) (Coleoptera: Coccinellidae) en la provincia de Buenos Aires. Aspectos biológicos y morfológicos. RIA 33: 151-160.

Sasaji, H. 1971. Fauna Japonica, Coccinellidae (Insecta: Coleoptera). Tokyo, Academic Press Japan, 340p.

Schanderl, H., A. Ferran \& M.M. Larroque. 1985. Les besoins trophiques et thermiques des larves de la coccinelle Harmonia axyridis Pallas. Agronomie-Sci. Prod. Veg. Environ. (Paris) 5: 417-421.

Sebolt, D.C. \& D.A. Landis. 2004. Arthropod predators of Galerucella calmariensis L. (Coleoptera: Chrysomelidae): An assessment of biotic interference. Environ. Entomol. 33: 356-361.

Sloggett, J.J. 2005. Are we studying too few taxa? Insights from aphidophagous ladybird beetles (Coleoptera: Coccinellidae). Eur. J. Entomol. 102: 391-398.

Soares, A.O., D. Coderre \& H. Schanderl. 2003. Effect of temperature and intraspecific allometry on predation by two phenotypes of Harmonia axyridis Pallas (Coleptera: Coccinellidae) Environ. Entomol. 32: 939-944

Stathas, G.J., P.A. Eliopoulos, D.C. Kontodima \& J. Giannopapas. 2001. Parameters of reproductive activity in females of Harmonia axyridis (Coleoptera: Coccinellidae). Eur. J. Entomol. 98: 547-549.

Sutherst, R.W., J.P. Spradbery \& G.F. Maywald. 1989. The potential geographical distribution of the Old World screw-worm fly, Chrysomya bezziana. Med. Vet. Entomol. 3: 273-280.

Tedders, W.L. \& P.W. Schaefer. 1994. Release and establishment of Harmonia axyridis (Coleoptera: Coccinellidae) in the southeastern United States. Entomol. News 105: 228-243.

Trouve, C., S. Ledee, A. Ferran \& J. Brun. 1997. Biological control of the damson-hop aphid, Phorodon humuli (Hom.:Aphididae), using the ladybeetle Harmonia axyridis (Col.: Coccinellidae). Entomophaga 42: 57-62.

Venette, R.C. \& D.W. Ragsdale. 2004. Assessing the invasion by soybean aphid (Homoptera: Aphididae): Where will it end? Ann. Entomol. Soc. Am. 97: 219-226.

Venette, R.C. \& W.D. Hutchison. 1999. Assessing the risk of establishment by pink bollworm (Lepidoptera: Gelechiidae) in the southeastern United States. Environ. Entomol. 28: 445455 . 
Wallace, M.S. \& F.P. Hain. 2000. Field surveys and evaluation of native and established predators of the hemlock wooly adelgid (Homoptera: Adelgidae) in the Southeastern United States. Environ. Entomol. 29: 638-644.

Wheeler, A.G. 1995. Multicolored Asian lady beetle, Harmonia axyridis (Pallas). Regul. Hortic. 21: 17-19.

Wise, I.L., R.E. Roughley \& W.J. Turnock. 2001. New Records of coccinellid species for the province of Manitoba. Proc. Entomol. Soc. Manit. 57: 5-10.

Xie, Y., J. Xue, X. Tang \& S. Zhao. 2004. The Bunge prickly-ash tree damaged by a mealybug, Phenacoccus azaleae, attracting the ladybug, Harmonia axyridis. Sci. Silvae Sin. 40: 116122.

Yasuda, H., E.W. Evans, Y. Kajita, K. Urakawa \& T. Takizawa. 2004. Asymmetrical larval interactions between introduced and indigenous lady birds in North America. Oecologia 141: 722-731.

Accepted 26/05/06. 